\title{
Inelastic X-ray scattering experiments at extreme conditions: high temperatures and high pressures
}

\author{
S.Hosokawa ${ }^{1,2}$ \\ ${ }^{1}$ Center for Materials Science using Third-Generation Synchrotron Radiation Facilities, Hiroshima Institute of \\ Technology, 2-1-1 Miyake, Saeki-ku, Hiroshima 731-5193, Japan \\ 2 Institut für Physikalische-, Kern-, und Makromolekulare Chemie, Philipps Universität Marburg, \\ Hans-Meerwein Str., 35032 Marburg, Germany
}

Received November 5, 2007

\begin{abstract}
In this article, we review the present status of experimental techniques under extreme conditions of high temperature and high pressure used for inelastic X-ray scattering (IXS) experiments of liquid metals, semiconductors, molten salts, molecular liquids, and supercritical water and methanol. For high temperature experiments, some types of single-crystal sapphire cells were designed depending on the temperature of interest and the sample thickness for the X-ray transmission. Single-crystal diamond X-ray windows attached to the externally heated high-pressure vessel were used for the IXS experiment of supercritical water and methanol. Some typical experimental results are also given, and the perspective of IXS technique under extreme conditions is discussed.
\end{abstract}

Key words: particle dynamics, inelastic $X$-ray scattering, high temperature, high pressure, liquid, supercritical fluid

PACS: $61.25 . \mathrm{Mv}, 61.25 . \mathrm{Em}, 61.10 . \mathrm{Eq}, 63.50 .+x$

\section{Introduction}

Since the advent of intense third-generation synchrotron facilities during the past decades, significant progress has been achieved in the development of modern X-ray scattering techniques. This advancement has stimulated renewed interest in the investigation of structure and dynamics of disordered matter, and has revived the efforts to explore the liquid state. For example, inelastic X-ray scattering (IXS) experiments can be performed with resolutions in the meV range using intense high-energy beamlines with brilliant scattering statistics. However, in order to sufficiently apply these remarkable possibilities to the liquid matter field, it is essential to develop new sample environments to extend the range of experimental opportunities. In particular, some metallic elements, such as transition metals, have very high melting temperatures far beyond $1000^{\circ} \mathrm{C}$, at which the liquid samples could hardly be kept stable for a long time. Thus, the IXS experiments for these liquid metals have not been performed so far although they have drawn much interest from fundamental and applied scientific viewpoints.

Single crystal sapphire having a high melting temperature of $2054{ }^{\circ} \mathrm{C}$, is essentially not corrosive against most of liquid materials even at high temperatures, and becomes almost transparent to hard X-rays by making windows with sub-mm thickness, which is possible by using diamond tools. Moreover, it has a very fast sound velocity of more than $10,000 \mathrm{~ms}^{-1}$, which does not interfere with inelastic excitation signals. Thus, single crystal sapphire is an ideal material for a sample container to perform IXS experiments of high-temperature liquids. Tamura and coworkers found these advantages of single-crystal sapphire as a liquid container [1], and used for energy-dispersive X-ray diffraction experiments of supercritical fluid $\mathrm{Hg}$ [2] at high temperatures up to $1530{ }^{\circ} \mathrm{C}$ under high pressure. This technique has continuously developed to carry out IXS study of supercritical fluid $\mathrm{Hg}$ [3].

Diamond is also an excellent material of X-ray transmission, and with fast sound velocity of $18,000 \mathrm{~ms}^{-1}$. It is, however, costly and difficult to machine, and thus, it has been used as high- 
pressure X-ray windows for supercritical water (SCW) and methanol (SCM). Supercritical fluids of molecules containing hydrogen bonds, such as SCW $\left(T_{c}=657 \mathrm{~K}, p_{c}=22.1 \mathrm{MPa}, \rho_{c}=0.32 \mathrm{gcm}^{-3}\right)$ and SCM $\left(T_{c}=513 \mathrm{~K}, p_{c}=8.1 \mathrm{MPa}, \rho_{c}=0.27 \mathrm{gcm}^{-3}\right)$, have been targets of recent research in fundamental and applied sciences, in particular in the field of green chemistry as a novel reaction medium for decomposition of hazardous organic chlorinated wastes, dioxin, and polychlorobiphenyl (PCB), and recovery of useful chemicals from industrial plastic wastes like polyethyleneneterephthalate (PET) [4]. Since the unique properties of SCW and SCM as solvents in chemical reactions arise from fluctuations in hydrogen bonding state and density (cluster formation), information on the structures and dynamic properties of SCW and SCM is thus highly needed for understanding the underlying mechanism in chemical reactions and for further development of supercritical fluids technology.

In this article, we review the status of the present experimental techniques that we used for liquid metals, semiconductors, molten salts, molecular liquids, and supercritical water and methanol to conduct IXS experiments under extreme conditions of high temperature and high pressure in the next section. Some typical experimental results are also reviewed in the subsequent section, and the prospects of IXS technique under extreme conditions in the concluding remarks section are discussed.

\section{Experimental}

\subsection{Vessel for high temperature experiments}

Figure 1 shows the (a) side and (b) top views of the internally heated high-pressure vessel [5] used for our IXS experiments of liquid metals, semiconductors, molten salts, and molecular liquids. It was designed for X-ray scattering experiments carried out in transmission mode. It consisted of a closed-end $\mathrm{Al}$ cylinder with an inner diameter of $60 \mathrm{~mm}$, an inner length of 170 $\mathrm{mm}$, and a minimum outer diameter of $80 \mathrm{~mm}$. The cylinder was closed with a steel flange of 30 $\mathrm{mm}$ thick. The flange was equipped with Bridgeman-type high-pressure leadthroughs for heaters and thermocouples. Corresponding details are given in [1]. High pressure was generated using high purity grade He gas, which has a low absorption constant for hard X-rays in the energy range of the IXS experiments. The temperature of the vessel was kept near room temperature using water cooling jackets placed around the cylinder.

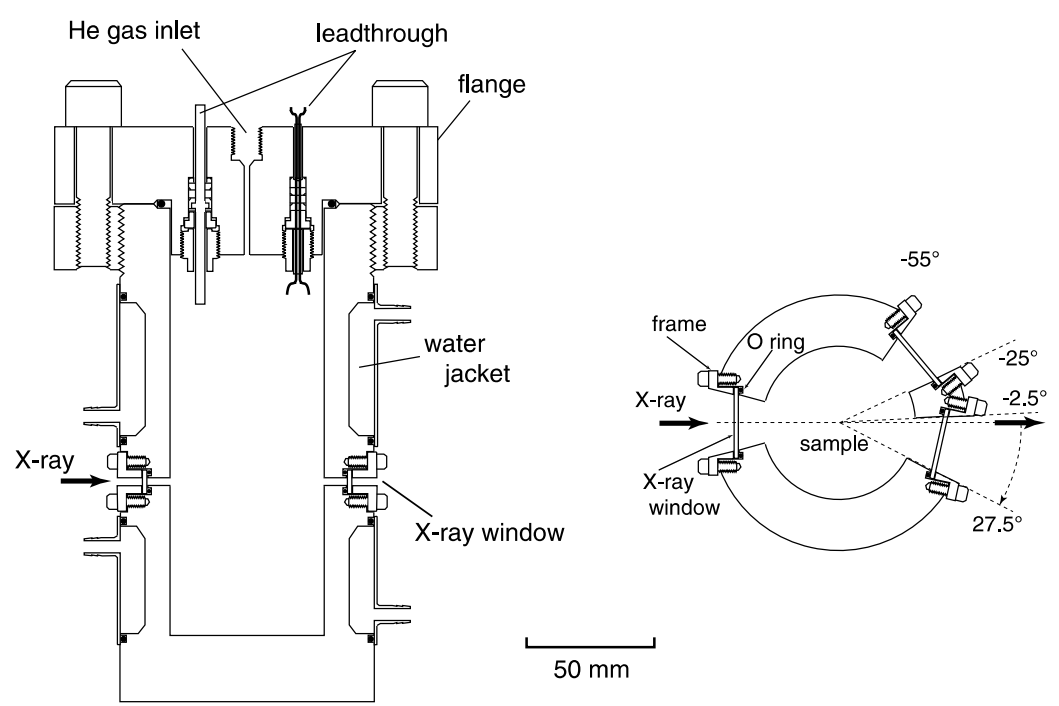

(a)

(b)

Figure 1. (a) Side and (b) top views of the internally heated high-pressure vessel [5]. 
As seen in figure 1(b), the cylinder was equipped with three X-ray windows for incident and scattered X-rays. They covered scattering angles $2 \theta$ from $-2.5^{\circ}$ to $27.5^{\circ}$ and from $25^{\circ}$ to $55^{\circ}$. For high-pressure experiments of more than $0.3 \mathrm{MPa}$, the X-ray window was a rectangular $\mathrm{Be}$ plate of $30 \mathrm{~mm}$ long, $10 \mathrm{~mm}$ wide, and $2 \mathrm{~mm}$ thick. The Be material was polycrystal, and had a purity of $99.999 \%$ machined at Heraeus GmbH, Germany. It had a relatively high background at energies near the quasielastic line, which may come from the polycrystalline phase and impurities of some metal elements such as $\mathrm{Mg}, \mathrm{Cu}$, and $\mathrm{Fe}(>0.5 \mathrm{ppm})$. In order to drastically reduce such a background, single crystal $\mathrm{Si}$ plate with a thickness of $0.5 \mathrm{~mm}$ was used for the low pressure experiment below $0.3 \mathrm{MPa}$. Each plate was fixed by a brass frame attached to the cylinder with about ten screws. Sealing the windows is accomplished by a rubber O ring. The slit holes in both the $\mathrm{Al}$ cylinder and the frame had a horizontal aperture of $30^{\circ}$ and a height of $3 \mathrm{~mm}$.

\subsection{Sapphire cells for high temperature experiments}

For samples with the melting point of lower than $1000^{\circ} \mathrm{C}$, a Tamura-type single-crystal sapphire cell was used for the IXS experiments of liquid metals such as $\mathrm{Na}$ [6], Ge [7,8], $\mathrm{Hg}[9]$, Sn [10], Ga [11], Te [12,13], liquid semiconductors such as Se [14], and molten salts such as $\mathrm{NaCl}[15]$ and $\mathrm{KCl}[16]$. The cell and the compact heating system for the sample are sectionally illustrated in figure 2(a), and the construction of the hot part is shown in figure 2(b) on an enlarged scale. Liquid samples were contained in a single-crystal, which is almost transparent to hard X-rays and resistant to chemical corrosion from the samples at high temperatures. Construction and manufacturing of the cell are in detail given in an instrumental paper [1]. A closed-end sapphire tube with an inner diameter of $2.5 \mathrm{~mm}$, an outer diameter of $3.5 \mathrm{~mm}$, and a length of $26.5 \mathrm{~mm}$ was inserted into another closed-end tube with an inner diameter of $3.5 \mathrm{~mm}$, an outer diameter of $4.5 \mathrm{~mm}$, and a length of $26 \mathrm{~mm}$. The closed ends act as the X-ray windows, whose thicknesses were about $0.2 \mathrm{~mm}$. The sapphire components were glued together by a high-temperature ceramics adhesive (SEM-COM Co. Inc., Type SCE-1) such that a uniform gap remained between the closed ends of the tubes. The width of the gap was adjusted to match the requirements for maximum scattering intensity from the respective liquid samples. A sample reservoir was also attached to the outer tube by the ceramics adhesive.
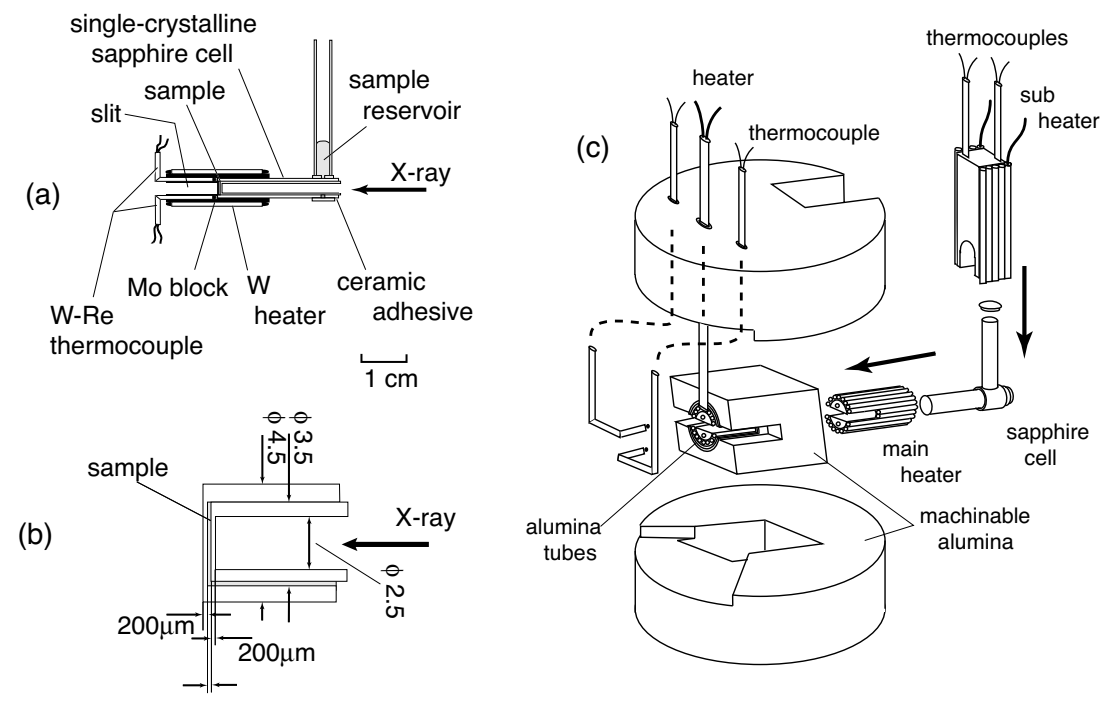

Figure 2. (a) Single crystal sapphire cell [1] for samples with the melting point of lower than $1000^{\circ} \mathrm{C}$ together with the compact heating system. (b) Enlarged view around the liquid sample for the IXS measurements. (c) The whole assembly of the cell and the heating system.

The cell was heated with a heating element manufactured from Mo or W resistant wire with a diameter of $0.5 \mathrm{~mm}$. The wire was electrically insulated with alumina tubes (Friedrichsfeld Co. Ltd., 
Type DEGUSSIT AL-23) with inner and outer diameters of $0.7 \mathrm{~mm}$ and $1.2 \mathrm{~mm}$, respectively. The zigzag shaped heater was wound around an Mo cylindrical block to ensure a uniform temperature distribution over the scattering volume. A horizontal slit on the scattering side of the Mo block made the X-ray scattering possible. The sample temperature was monitored and controlled using two W-5\%Re:W-26\%Re thermocouples. They were inserted through the holes on the front part of the Mo block, and were in contact with the outer wall of the sapphire cell close to the sample volume. A similar Mo heater was used to keep the sample reservoir at a temperature above the melting point of the sample. To improve the heat transfer and temperature homogeneity, the reservoir was additionally covered with a metallic hood.

Figure 2(c) shows the whole assembly of the cell and the heating system. The whole assembly was placed in massive blocks of porous machinable alumina (Cotronics Co., Type 960, 96\% $\mathrm{Al}_{2} \mathrm{O}_{3}$ ). These parts provide thermal insulation and suppress convection of the He gas. Since the machinable alumina deforms beyond $1600^{\circ} \mathrm{C}$, the heating assembly was inserted into two additional alumina tubes (Friedrichsfeld Co. Ltd., Type DEGUSSIT AL-23) to suppress the heat flow from the hot heating system.

The following procedure describes how the sample space was filled between the closed ends of the cell with the liquid sample. First, the solid sample was put into the sample reservoir of the cell. After closing the high-pressure seals, the entire assembly was evacuated. Then, the sample reservoir was heated up in order to melt the sample, and the vessel was filled with He gas at normal pressure that was sufficient to force the molten sample through a small channel and fill the sample space. Once the cell had been filled, the temperature of the reservoir was maintained near the melting point. Pressure balance between the compressed liquid sample and the He gas was achieved through the sample reservoir. The background was measured by heating the sample part without the sample up to the same temperature of the sample measurement before heating and filling the sample, and was used for the data correction.

If the melting temperature of the sample is higher than $1000^{\circ} \mathrm{C}$, this type of cell can no longer be used for the IXS experiment because the high-temperature ceramics adhesive (SEM-COM Co. Inc., Type SCE-1) softens around $1000^{\circ} \mathrm{C}$, and the sample cannot be kept in the sample reservoir. Instead, a reservoir-less cell was designed as illustrated in figure 3, and used for the high-melting temperature liquid metals such as $\mathrm{Si}$ [17], $\mathrm{Fe}[18,19], \mathrm{Ni}[20]$, and $\mathrm{Cu}[21]$. As seen in the figure, a sample with an appropriate thickness for the X-ray transmission was sandwiched with two closedend tubes with the same sizes of figure 2. Then, the tubes were cemented and closed by the high-temperature ceramics adhesive under He gas atmosphere in order to fix the sample thickness even after melting and to avoid the chemical corrosion between the sample vapour and the metal heating wire at high temperatures. It was placed in the same heating system shown in figure 2(c), which can heat the sample up to $1700^{\circ} \mathrm{C}$. Due to low wetting natures with sapphire and high surface tensions of liquid metals, the thin films of liquid metal samples can easily be kept between the gap of the closed ends of the sapphire cell. When the power of the heating system was not sufficient to attain the heating up to the objective temperature, another heating wire was wound outside the main heater to help heating the high melting temperature sample such as $\mathrm{Fe}, \mathrm{Ni}$, and $\mathrm{Cu}$.

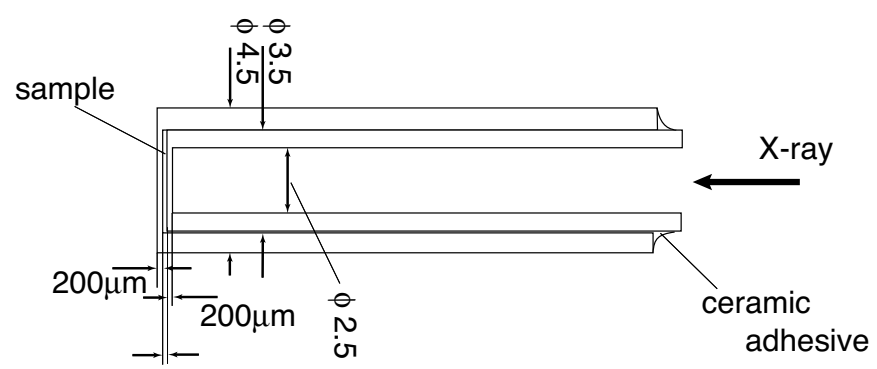

Figure 3. Cross section of single crystal sapphire cell for samples with the melting point of higher than $1000^{\circ} \mathrm{C}$. 
If the sample temperature of interest was lower than $1000^{\circ} \mathrm{C}$ and the sample thickness was larger than $0.2 \mathrm{~mm}$, another type of the cell was used for the convenience of conducting the IXS experiments, such as for liquid S [22], molten $\mathrm{NaI}$ [23] and $\mathrm{CsCl}$ [24], and several molecular liquids [25]. Figure 4(a) shows sectional view of the convenient single-crystal sapphire cell, and figure 4(b) illustrates stereographic view of the sapphire column for the outgoing X-ray window. Two single crystal sapphire short columns were drilled and polished by diamond tools and diamond pastes to make the X-ray windows. The X-ray windows were polished to be a thickness of $0.25 \mathrm{~mm}$. A ditch was made in one of the sapphire columns for the scattered X-rays as seen in figure 4(b). The columns were fixed with an alumina tube (Friedrichsfeld Co. Ltd., Type DEGUSSIT AL-23) by high-temperature ceramics adhesive (SEM-COM Co. Inc., Type SCE-1) so that the X-ray windows were facing each other having an adequate gap for the sample thickness. The sample reservoir was attached directly outside the alumina tube.

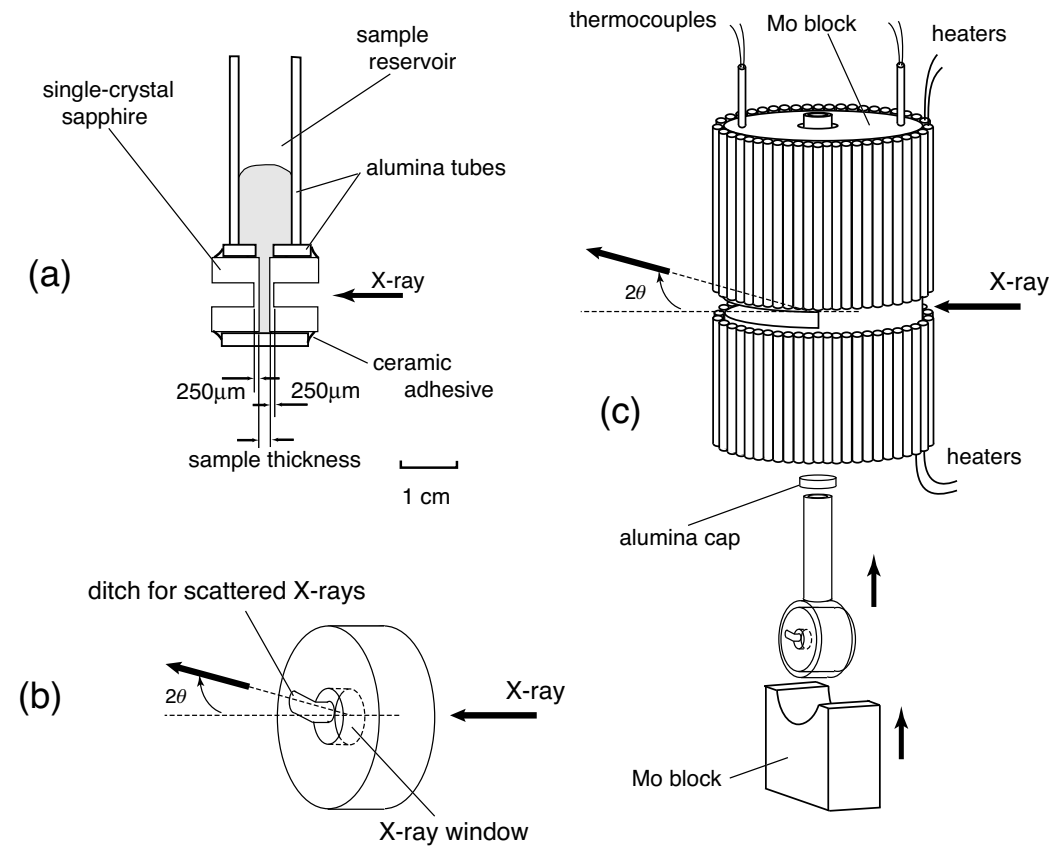

Figure 4. (a) Sectional view of convenient single-crystal sapphire cell for measurements at sample temperatures of lower than $1000^{\circ} \mathrm{C}$. (b) Stereographic view of the outgoing X-ray window of the cell. (c) The whole assembly of the cell and the heating system.

As seen in figure 4, the cell was encapsulated in blocks made of Mo, which has a hole for the incoming X-rays and a slit for the scattered X-rays. The Mo blocks were wound by zigzagtype Mo heaters with a diameter of $0.5 \mathrm{~mm}$ with the alumina insulation tubes, and worked for a uniform temperature distribution over the scattering volume. The temperature was monitored and controlled by two W-5\%Re:W-26\%Re thermocouples located near the incident and scattered X-ray windows through the holes in the upper Mo block. To avoid condensation of the sample vapour around the X-ray windows, the top of the sample reservoir was set outside the Mo block, and was encapped with an alumina piece. The whole setup was placed in the vessel shown in figure 1.

\subsection{High-temperature high-pressure cell for supercritical water and methanol}

Figure 5 shows a high-temperature high-pressure cell or an externally heated high-pressure vessel (Toyo Koatsu Co. Ltd.) used for the IXS experiments of supercritical water [26] and methanol [27]. The vessel was made of Inconel 625 alloy, which does not chemically react with the supercritical water and methanol. The sample was degassed and filled in the vessel. Two synthetic single crystal 
diamond windows (Sumutomo Electric Ind. Co. Ltd.) with a thickness of $1 \mathrm{~mm}$ and a diameter of $5 \mathrm{~mm}$ were equipped in the vessel for the incoming and outgoing X-rays. The diamond windows were supported by metal sleeves. The aperture of the sleeves was about $20^{\circ}$, which provided the scattering angle up to about $20^{\circ}$ by rotating the vessel. The sleeves were sealed by using hollow

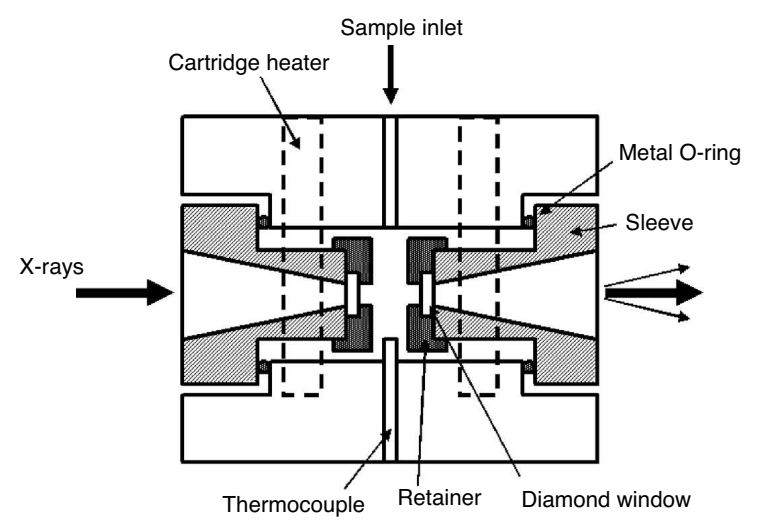

Figure 5. Cross section of a high-temperature high-pressure IXS cell.

metal $\mathrm{O}$ rings. High temperatures up to $400^{\circ} \mathrm{C}$ were achieved by using four cartridge heaters set in the holes of the vessel. The temperature was monitored and controlled by a chromel-alumel thermocouple placed in the fluid sample. The stability of the temperature was within $0.1 \mathrm{~K}$. The pressure was measured using a Heise gauge with a resolution of $0.02 \mathrm{MPa}$. The vessel was placed in a vacuum chamber with thin Kapton windows to suppress strong background scattering by the surrounding air. This vessel was originally designed by Yamaguchi [28] for XAFS and X-ray diffraction experiments for supercritical water and its solutions, and modified by only replacing the polycrystal diamond X-ray windows with single crystal ones.

\section{Examples of results}

Using the above equipment, we have carried out IXS experiments for several liquid systems at high temperatures under normal or high pressure. Three typical examples of the IXS experiments will be reviewed in the following subsections.

\subsection{Liquid metals}

In a monatomic liquid, the excitation lifetime is shortened by the heat flow effects and viscous drag forces. The width of the inelastic excitation peaks $W Q^{2}$ can be estimated from the values of macroscopic thermodynamic quantities within the thermodynamic limit, expressed as [29]

$$
\left.W=\left[(\gamma-1) D_{\mathrm{T}}+\nu\right)\right] / 2
$$

where $\gamma$ is the ratio of specific heats at constant pressure and constant volume, $D_{\mathrm{T}}$ is the thermal diffusivity, and $\nu$ is the longitudinal kinematic viscosity. Liquid Fe has a large $\gamma$ value of 1.72 and a shear viscosity value of 5.5 MPas, by which a highly damping feature of the phonon excitation modes was expected within the hydrodynamic context.

The IXS measurement of liquid Fe $[18,19]$ was performed at $1570^{\circ} \mathrm{C}$ near the melting point at BL35XU of SPring-8 using the high-temperature reservoir-less sapphire cell shown in figure 3. $1570^{\circ} \mathrm{C}$ is the highest temperature at which the IXS experiments have been carried out with a liquid container so far. Figure 6(a) shows the selected IXS spectra normalized to the corresponding integral. Also given as a dashed line is a typical example of the resolution function.

In contrast to the above hydrodynamic prediction, clear inelastic excitations are seen as peaks or shoulders at both the sides of the central quasielastic line, and the energy of inelastic contributions 
(a)

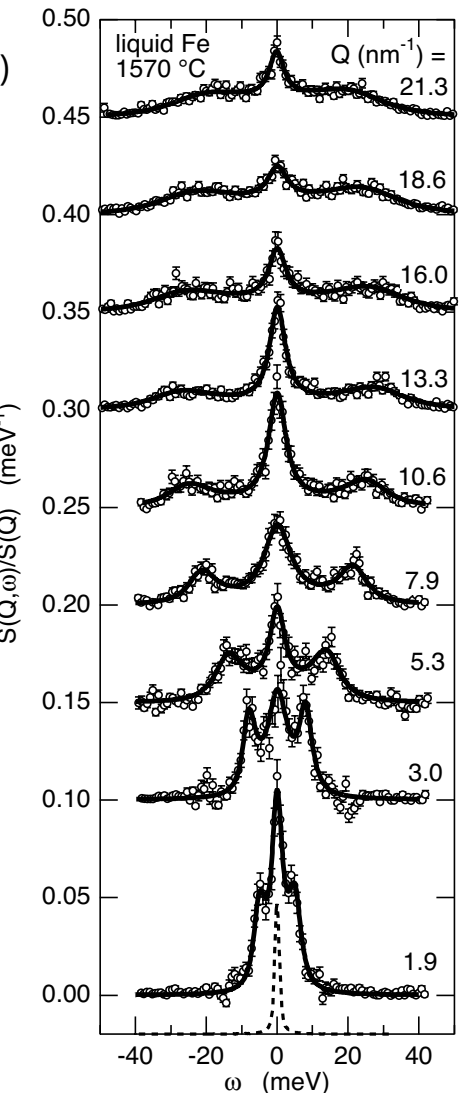

(b)

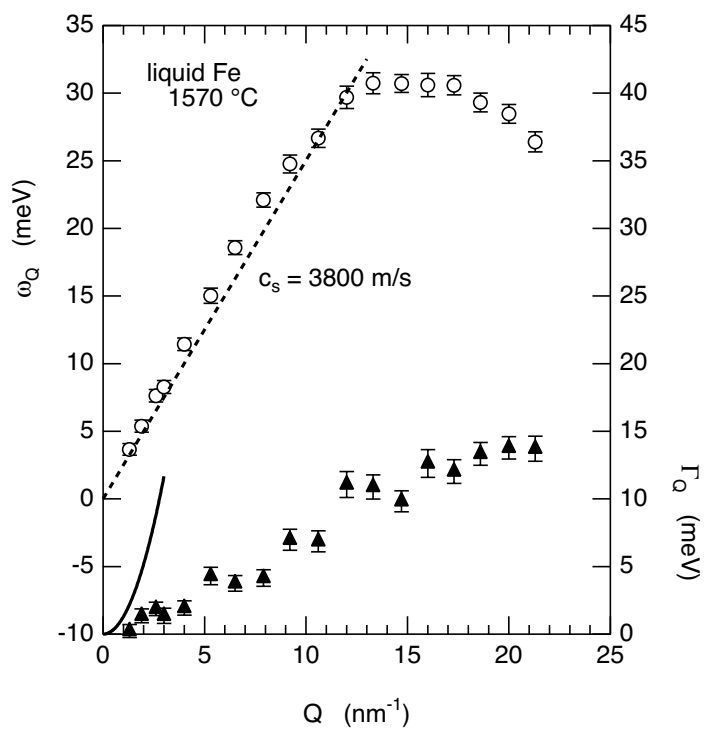

Figure 6. (a) Selected IXS spectra of liquid Fe at $1570^{\circ}$ C. (b) Dispersion relation (circles) and width (triangles) of the inelastic excitations obtained from DHO model [31]. See the text for details.

shifts with the increasing $Q$. Figure $6(\mathrm{~b})$ exhibits the excitation energy $\omega_{\mathrm{Q}}$ (circles) and the width $\Gamma_{\mathrm{Q}}$ (triangles) of the inelastic excitations obtained from a damped harmonic oscillator (DHO) model [31]. The dispersion of the phonon excitation in the low $Q$ region deviates by about $11 \%$ from that predicted by hydrodynamic sound velocity given by a dashed line in the figure. With increasing $Q, \Gamma_{\mathrm{Q}}$ slowly and almost linearly increases, while the hydrodynamic theory using the macroscopic thermodynamic data for equation (1) predicted a very rapid increase that is proportional to $Q^{2}$ as shown by the solid curve in figure $6(\mathrm{~b})$. This result on the excitation width indicates that the $Q$ range of the present IXS experiment is already outside of where the hydrodynamic theory can be applied. This inconsistency of the damping feature has been solved [19] by applying the modified version of the generalized ( $Q$ dependent) hydrodynamic theory [30].

\subsection{Molten salts}

There are two recent topics for the study of the dynamics in molten salts: 1) In what way is the acoustic phonon dynamics of the Coulomb liquids different from liquid metals? 2) Does the optic-like mode appear in the IXS spectra? The dynamic structure factor of molten $\mathrm{CsCl}$ was measured at $720^{\circ} \mathrm{C}$ at BL35XU/SPring-8 [24] using a slightly modified version of the convenient sapphire cell shown in figure 4. Figure 7(a) illustrates a perspective view of the IXS spectra of molten $\mathrm{CsCl}$. In contrast to those of liquid metals, the phonon excitation modes can be hardly seen as a peak. This is due to the slower velocity of sound. Nevertheless, the inelastic excitations can be observed through the DHO analysis [31]. Figure 7(b) shows the dispersion relation (circles) and width (triangles) of the inelastic excitations obtained from DHO model. 

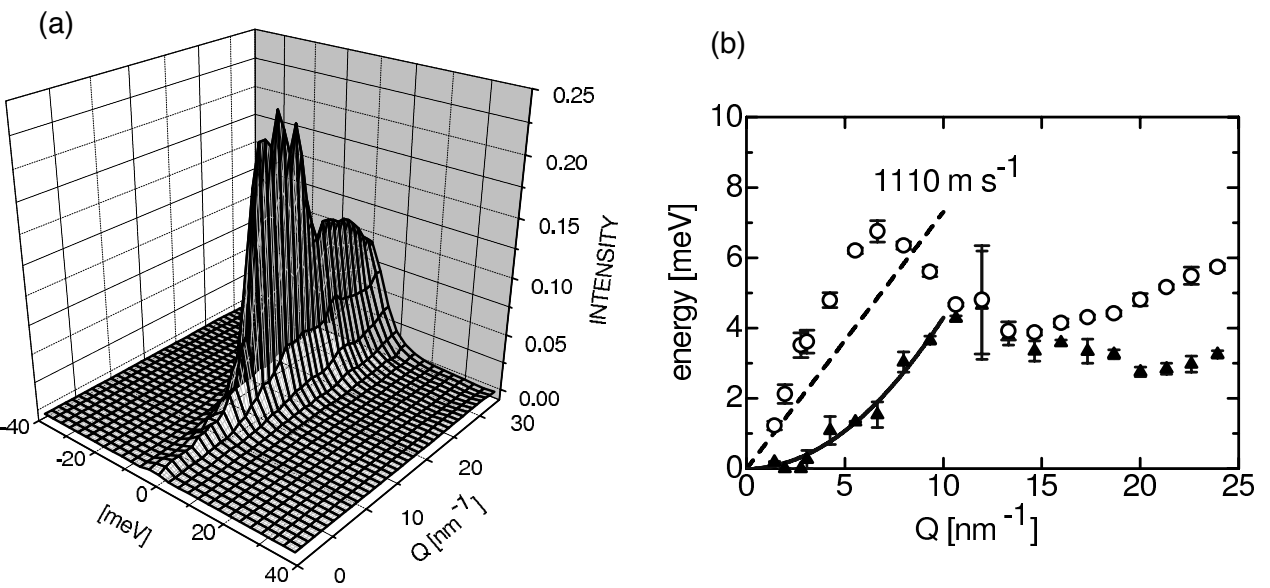

Figure 7. (a) A perspective plot of IXS spectra of molten $\mathrm{CsCl}$ at $720^{\circ} \mathrm{C}$. (b) Dispersion relation (circles) and width (triangles) of the inelastic excitations obtained from DHO model. See the text for details.

As seen in the figure, the dispersion of the phonon excitation in the low $Q$ region largely deviates by about $70 \%$ from that predicted by hydrodynamic sound velocity given by a dashed line, which was found earlier in other molten salts [15,16,23], and extremely larger than those in liquid metals. With increasing $Q$, the linewidth increases following the $Q^{2}$ law up to about $10 \mathrm{~nm}^{-1}$ as predicted by the hydrodynamics. However, the linewidth is a factor of seven smaller than the estimation using a Brillouin light scattering result. The large speed-up and the significant narrowing of the collective mode observed in molten $\mathrm{CsCl}$ can be related to each other by a recently presented viscoelastic theory [30], and must arise from the intrinsic nature of molten alkali chlorides. Furthermore, in comparison with the previous results for molten $\mathrm{NaCl}$ [15] and $\mathrm{KCl}$ [16], the apparent sound velocity is found to be approximately scaled by the inverse of the square-root of effective mass among these molten salts.

Distinct excitations of the optic-like modes cannot be observed in the present spectra of molten $\mathrm{CsCl}$ although the large difference in the atomic form factor between $\mathrm{Cs}$ and $\mathrm{Cl}$ elements has got an advantage of observing them. This may be due to a highly damping feature of the optic-like modes as suggested by an INS results [32].

\subsection{Supercritical water and methanol}

The IXS spectra of sub- and supercritical water was measured at BL35XU of SPring-8 at densities from about $1 \mathrm{gcm}^{-3}$ in ambient conditions to $0.263 \mathrm{gcm}^{-3}$ in the supercritical region [26]. The measurements were performed in the $Q$ range $1.3-10.7 \mathrm{~nm}^{-1}$ and in the $\omega$ range $\pm 40 \mathrm{meV}$. Figure 8(a) shows logarithmic plots of selected IXS spectra normalized to the respective integral intensity at $Q=4.0 \mathrm{~nm}^{-1}$ at different $\rho$ values. Circles represent the experimental data with error bars, and the dashed curve shows the resolution function. In the ambient conditions $\left(\rho=0.997 \mathrm{gcm}^{-3}\right)$, inelastic excitation modes are seen at the both sides of the central peak, and the excitation energies are highly $(\sim 100 \%)$ deviated from the hydrodynamic value $c_{\mathrm{S}}$. With decreasing $\rho$, the energy position of the inelastic excitation rapidly shifts to the lower energies, and the shoulders merge into the quasielastic line.

The spectra were analyzed using a generalized Langevin formalism with a memory function of thermal and viscoelastic relaxations to obtain the energy of the inelastic excitation modes $\omega_{\mathrm{Q}}$. Figure $8(\mathrm{~b})$ exhibits the $\rho$ dependence of the dynamical velocity of sound $c_{\mathrm{Q}}=\omega_{\mathrm{Q}} / Q$ at $Q=2.6 \mathrm{~nm}^{-1}$ (empty circles) and $Q=9.4 \mathrm{~nm}^{-1}$ (full circles). Also given is the hydrodynamic velocity of sound $c_{\mathrm{S}}$ as a dashed curve. In ambient conditions of $\rho \sim 1 \mathrm{gcm}^{-3}$, the $c_{\mathrm{Q}}$ values are about $3,000 \mathrm{~ms}^{-1}$, almost twice as large as the $c_{\mathrm{S}}$ value of about 1,500 $\mathrm{ms}^{-1}$. With decreasing $\rho$, $c_{\mathrm{Q}}$ rapidly decreases, and approaches the $c_{\mathrm{S}}$ vale at $\rho \sim 0.8 \mathrm{gcm}^{-3}$. With a further decrease of $\rho$, 


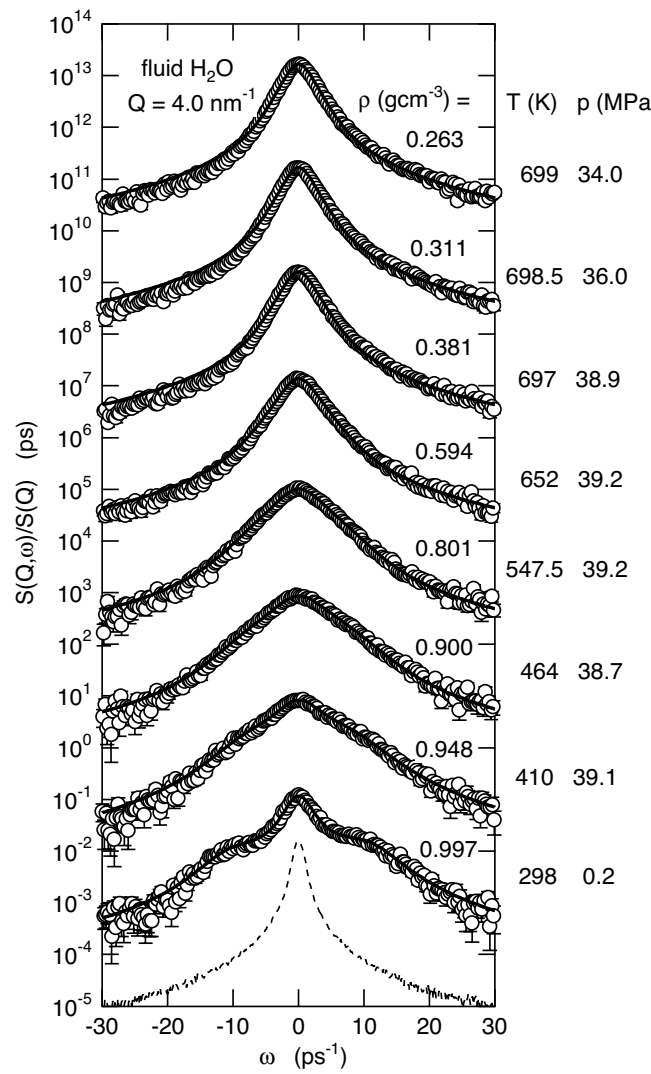

(a)

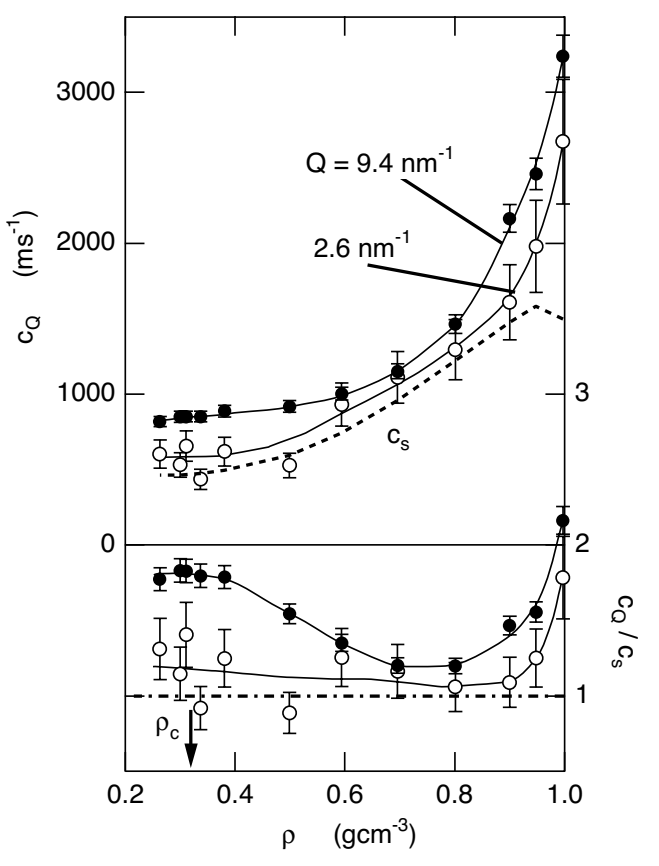

(b)

Figure 8. (a) Logarithmic plots of selected IXS spectra normalized with the respective integral as a function of $\omega$ at $Q=4.0 \mathrm{~nm}^{-1}$ at different densities $\rho$. (b) Top: $\rho$ dependence of dynamical velocity of sound $c_{\mathrm{Q}}=\omega_{\mathrm{Q}} / Q$ at $Q=2.6 \mathrm{~nm}^{-1}$ (empty circles) and $Q=9.4 \mathrm{~nm}^{-1}$ (full circles). The dashed curve indicates the adiabatic sound velocity $c_{\mathrm{s}}$. Bottom: The ratio $c_{\mathrm{Q}} / c_{\mathrm{s}}$. The arrow indicates the critical density $\rho_{c}=0.32 \mathrm{gcm}^{-3}$.

$c_{\mathrm{Q}}$ at $Q=2.6 \mathrm{~nm}^{-1}$ decreases along with the $c_{\mathrm{S}}$ curve, while $c_{\mathrm{Q}}$ at $Q=9.4 \mathrm{~nm}^{-1}$ starts to deviate again from the $c_{\mathrm{s}}$ value. The ratio $c_{\mathrm{Q}} / c_{\mathrm{s}}$ gives a much prominent trend as seen in the bottom panel of figure $8(\mathrm{~b})$. The $c_{\mathrm{Q}}$ value at $Q=9.4 \mathrm{~nm}^{-1}$ shows about $80 \%$ positive value around the critical density $\rho_{c}=0.32 \mathrm{gcm}^{-3}$, while the $c_{\mathrm{Q}}$ value at $Q=2.6 \mathrm{~nm}^{-1}$ locates slightly larger than the hydrodynamic value shown as a chain line.

From these results, the authors suggested that the initial decrease of the dynamical velocity of sound is due to approaching the percolation limit in the number of hydrogen bonds, and the subsequent increase is due to the formation of rigid dimers in sub- and super critical water. Similar results were obtained in the density dependence of the IXS spectra of sub- and supercritical methanol [27].

\section{Concluding remarks}

In this article we describe our recent status of high-temperature experimental technique for liquids with high melting points using several types of single-crystal sapphire cells. The high temperature IXS experiment using a liquid sample container made of single-crystal sapphire has nowadays become a well-matured technique by the rich experimental experiences in almost two decades, and useful information on the particle or molecular dynamics of various kinds of liquids has been obtained using the single-crystal sapphire sample container. For elements with a higher melting 
temperature, container-less methods with laser heating have made it possible to carry out highenergy X-ray scattering. However, the spatial stability of the liquid sample with a sub-mm size should be realized in order to conduct the IXS experiment.

A high-temperature high-pressure cell with diamond windows for supercritical fluid water and methanol is also reviewed in this manuscript. It can essentially be applied to supercritical phases of other molecular liquids if the temperature is limited up to $400^{\circ} \mathrm{C}$. If the higher temperature is needed or the sample is more corrosive, it is necessary to find another stable metal material for the high-temperature high-pressure cell.

\section{Acknowledgements}

The IXS experiments of liquid metals, semiconductors, molten salts, and molecular liquids were carried out under the collaboration with Professor W.-C. Pilgrim of Philipps Universität Marburg, Dr. F. Demmel of ISIS, Dr. H. Sinn of HASYLAB/DESY, Professor S. Takeda and Dr. Y. Kawakita of Kyushu University, Professor M. Inui of Hiroshima University, Dr. Y. Katayama of Japan Atomic Energy Agency, Professor T. Kamiyama of Hokkaido University, Dr. A. Q. R. Baron and Dr. S. Tsutsui of SPring-8, and Dr. E. E. Alp of APS. The supercritical water and methanol experiments were performed with Professor T. Yamaguchi and Dr. K. Yoshida of Fukuoka University and Bl35XU/SPring-8 staff. The authour greatly appreciates Dr. M. Krisch, Dr. G. Monaco, and ESRF IXS beamline staff for conducting the IXS experiments at ESRF. The IXS experiments were performed at the beamline ID16 and ID28 of the ESRF (Proposal No. SC366, HS849, HS1154, HS1504, HS1644, HS1648, HS1988, HS2434, and HS2671), at the beamline 3-ID-C of the APS (Proposal No. II-76 and II-325), and at the beamline BL35XU of the SPring-8 (Proposal No. 2001B0482, 2002A0182, 2002B0179, 2003A0081, 2003A0153, 2003B0574, 2003B0766, 2004B0635, 2005A0567, 2005B0346, 2006A1376, and 2007A1109). The IXS works at the APS were supported from US DOS BES Material Science, Contract No. W-31-109-ENG-38.

\section{References}

1. Tamura K., Inui M., Hosokawa S., Rev. Sci. Instrum., 1999, 70, 144.

2. Tamura K., Hosokawa S., J. Phys.: Condens. Matter, 1994, 6, A241; Phys. Rev. B, 1999, 58, 9030.

3. Ishikawa D., Inui M., Matsuda K., Tamura K., Tsutsui S., Baron A.Q.R., Phys. Rev. Lett., 2004, 93, 097801; Inui M., Ishikawa D., Matsuda K., Tamura K., Baron A.Q.R., this volume.

4. Sako T., Sato M., Industrial Materials - Kogyo Zairyo, 1996, 44, 119 (in Japanese).

5. Hosokawa S., Pilgrim W.-C., Rev. Sci. Instrum., 2001, 72, 1721.

6. Pilgrim W.-C., Hosokawa S., Saggau H., Sinn H., Burkel E., J. Non-Cryst. Solids, 1999, 250-252, 96.

7. Hosokawa S., Kawakita Y., Pilgrim W.-C., Sinn H., Phys. Rev. B, 2001, 63, 134205.

8. Hosokawa S., Kawakita Y., Pilgrim W.-C., Sinn H., Physica B, 2002, 316-317, 610.

9. Hosokawa S., Sinn H., Hensel F., Alatas A., Alp E.E., Pilgrim W.-C., J. Non-Cryst. Solids, 2002, 312314, 163.

10. Hosokawa S., Greif J., Demmel F., Pilgrim W.-C., Chem. Phys., 2003, 292, 253.

11. Hosokawa S., Pilgrim W.-C., Sinn H., Alp E.E., Physica B, 2004, 350, 262.

12. Hosokawa S., Demmel F., Pilgrim W.-C., Albergamo F., J. Non-Cryst. Solids, 2006, 352, 5114.

13. Kajihara Y., Inui M., Hosokawa S., Matsuda K., Baron A.Q.R, J. Phys.: Conf. Ser., 2008, 98, 022001.

14. Inui M., Hosokawa S., Matsuda K., Tsutsui S., Baron A.Q.R., J. Phys. Soc. Jpn., 2007, 76, 053601.

15. Demmel F., Hosokawa S., Lorenzen M., Pilgrim W.-C., Phys. Rev. B, 2004, 69, 012203.

16. Demmel F., Hosokawa S., Pilgrim W.-C., J. Alloys Compd., 2008, 452, 143.

17. Hosokawa S., Pilgrim W.-C., Kawakita Y., Ohshima K., Takeda S., Ishikawa D., Tsutsui S., Tanaka Y., Baron A.Q.R., J. Phys.: Condens. Matter, 2003, 15, L623.

18. Hosokawa S., Inui M., Matsuda K., Ishikawa D., Baron A.Q.R., J. Phys.: Conf. Ser., 2008, 98, 022004.

19. Hosokawa S., Inui M., Matsuda K., Ishikawa D., Baron A.Q.R., Phys. Rev. B, submitted.

20. Cazzato S., Hosokawa S., Inui M., Pilgrim W.-C., Scopigno T., J. Chem. Phys., submitted.

21. Hosokawa S., Inui M., Kajihara Y., Baron A.Q.R., Phys. Rev. B, in preparation.

22. Katayama Y., Hosokawa S., Tsutsui S., Baron A.Q.R., unpublished.

23. Demmel F., Hosokawa S., Pilgrim W.-C., Tsutsui S., Nucl. Instrum. Met. Phys. Res. B, 2005, 238, 98. 
24. Inui M., Hosokawa S., Kajihara Y., Matsuda K., Tsutsui S., Baron A.Q.R., J. Phys.: Condens. Matter, 2007, 19, 466110.

25. Kamiyama T., Hosokawa S., Baron A.Q.R, Tsutsui S., Yoshida K., Pilgrim W.-C., Kiyanagi Y., Yamaguchi T., J. Phys. Soc. Jpn., 2004, 73, 1615.

26. Yamaguchi T., Yoshida K., Yamamoto N., Hosokawa S., Inui M., Baron A.Q.R., Tsutsui S., J. Phys. Chem. Solids, 2005, 66, 2246.

27. Yoshida K., Yamamoto N., Hosokawa S., Baron A.Q.R., Yamaguchi T., Chem. Phys. Lett., 2007, 440, 210.

28. Yamaguchi T., unpublished.

29. For example, Boon J.P., Yip Y. Molecular Hydrodynamics. McGraw-Hill, New-York, 1980.

30. Scopigno T., Balucani U., Ruocco G., Sette F., J. Phys. Condens. Matter, 2000, 12, 8009; Scopigno T., Ruocco G., Phys. Rev. E, 2004, 70, 013201.

31. Fåk B., Dorner B., 1992, Institut Laue-Langevin Reports, 92FA008S.

32. McGreevy R.L., Mitchell E.W.J., Margaca F.M., Howe M.A., J. Phys. C: Solid State Phys, 1985, 18, 5235 .

\title{
Експерименти по непружному розсіянню рентгенівських променів при екстремальних умовах: високі температури та високі тиски
}

\author{
Ш.Хосокава ${ }^{1,2}$ \\ 1 Центр матеріалознавства та Центр синхротронної радіації третього покоління, Хіросімський \\ технологічний інститут, Хіросіма, Японія \\ 2 Інститут фізичної, ядерної та макромолекулярної хімії, Філіпс університет Марбурґа, Марбурґ, \\ Німеччина
}

Отримано 5 листопада 2007 р.

У даній статті ми робимо огляд сучасного стану експериментальних методик при екстремальних умовах високих температур та високих тисків у експериментах з непружного розсіяння рентгенівських променів для рідких металів, напівпровідників, розплавів солей, молекулярних рідин, та надкритичних води і метанолу. Для експериментів при високих температурах було розроблено деякі типи монокристалічних сапфірових комірок, в залежності від температури та ширини зразка для проходження рентгенівських променів. Монокристалічні алмазні вікна для рентгенівських променів, під'єднані до комірки, що витримує високий тиск та має зовнішнє нагрівання, використовувались для експериментів по непружному розсіянню рентгенівських променів у надкритичних воді та метанолі. Також подано деякі типові експериментальні результати та обговорюється перспектива методики непружного розсіяння рентгенівських променів при екстремальних умовах.

Ключові слова: частинкова динаміка, непружне розсіяння рентгенівських променів, висока температура, високий тиск, рідина, надкритичний флюїд

PACS: $61.25 . \mathrm{Mv}, 61.25 . \mathrm{Em}, 61.10 . \mathrm{Eq}, 63.50 .+\mathrm{x}$ 
